\title{
Fibronectin and immune complexes in rheumatic diseases
}

\author{
K E HERBERT ${ }^{1}$ J S COPPOCK ${ }^{1}$ A M GRIFFITHS ${ }^{1}$ A WILliaMS ${ }^{2}$ \\ $M$ W ROBINSON, ${ }^{3}$ AND D L SCOTT ${ }^{1}$
}

From the Departments of ${ }^{1}$ Rheumatology and ${ }^{2}$ Chemical Pathology, St Bartholomew's Hospital and Medical $\vec{\circ}$ College, West Smithfield, London; and the ${ }^{3}$ Department of Rheumatology, University of Birmingham, Birmingham

SUMmARY The relation between fibronectin and immune complexes in rheumatic diseases was? examined in a series of linked studies. Fibronectin was present in immune complexes formed in के vitro in the absence of C1q. Gel filtration chromatography showed complexed fibronectin was $\vec{O}$ present in the serum of a patient with rheumatoid vasculitis, but not in normal serum; the $\omega$ complexed fibronectin coeluted with $\operatorname{IgA}$ and C3. Two dimensional immunoelectrophoresis ${ }_{\circ}^{+}$ showed a single fibronectin component was present in normal serum, but a number of $\stackrel{\odot}{\supset}$ components were present in serum from a rheumatoid patient. Polyacrylamide gel electro- $\vec{\circ}$ phoresis followed by immunoblotting for fibronectin showed that polyethylene glycol precipitates? of synovial fluid contained immunoreactive components of a variety of sizes, indicating the ${ }_{\mathbb{D}}$ presence of fragments of the molecule. An analysis of fibronectin in polyethylene glycol precipitates of paired serum and synovial fluid samples from 17 patients with rheumatoid arthritis $\infty_{\infty}$ and 16 with osteoarthritis showed more fibronectin was present in rheumatoid samples, especialfy. in synovial fluid. More fibronectin was also present in synovial fluid than in serum polyethylete glycol precipitates; there was no direct relationship with $\mathrm{C} 1 \mathrm{q}$ levels. All these results suggest that fibronectin is an integral component of immune complexes. This has potential pathogenic significance because it shows that a product of connective tissue cells may influence the functions $\frac{\mathscr{D}}{\infty}$ of the immune system.

Immune complexes (IC) are involved in the pathogenesis of rheumatoid arthritis and other connective tissue diseases. Their persistence in pathological fluids is influenced by the efficiency of their phagocytosis by cells. Recent evidence has suggested that a connective tissue protein, fibronectin, may be associated with immunoglobulins and complement components in IC. ${ }^{1-4}$ Fibronectin is a high molecular weight glycoprotein (440 000500000 ) of plasma, tissue fluids, and tissues. It binds to macromolecules such as collagen, heparin, and fibrin, ${ }^{5-8}$ adheres to cells, ${ }^{9}$ and is a major opsonin of particulate material in plasma. ${ }^{10-12}$ This opsonic role could be important in facilitating removal of IC from tissue fluids.

Several studies have provided evidence that fibronectin is a potential constituent of immune complexes; it binds to $\mathrm{C} 1 \mathrm{q},{ }^{13}$ to IgM rheumatoid

Accepted for publication 10 May 1987.

Correspondence to Dr D L Scott, Department of Rheumatology, St Bartholomew's Hospital, West Smithfield, London EC1A 7BE factor, ${ }^{4}$ and to complexes formed experimentally by heating $\mathrm{IgG}^{2}$; and it is a component of serum? polyethylene glycol (PEG) precipitates. ${ }^{1}$ These re-@ sults may have other explanations unrelated to $a$ o role for fibronectin in IC formation. The presence of fibronectin in PEG precipitates could be explained by its cryoprecipitable properties ${ }^{14} 15$; by precipitation of large proteins by PEG and by adherence of fibronectin to denatured protein.

Because of these questions we have further studied in detail the relation between fibronectine. and IC formation in rheumatic diseases. Our objecన్ tives were to define the relation between fibronectin and circulating IC, to evaluate the nature of complexed fibronectin, and to investigate the rela- $\omega$ tion between fibronectin and $\mathrm{Clq}$ in IC.

\section{Materials and methods}

FORMATION OF IN VITRO IMMUNE

COMPLEXES
IC were formed by mixing purified human IgM? 
(Sigma, Poole, Dorset, UK) at a final concentration of $20 \mu \mathrm{g} / \mathrm{ml}$ in phosphate buffered saline (PBS), $\mathrm{pH}$ $7 \cdot 4$, with goat antihuman IgM (Dakopatts, High Wycombe, UK) 1:40 in PBS (total volume $1 \mathrm{ml}$ ), in the presence or absence of fibronectin $(0.33 \mathrm{mg} / \mathrm{ml})$, for four hours at room temperature. These amounts of antigen and antibody were those required to reach the equivalence point as indicated by the manufacturer. Complexed proteins were precipitated by $2 \%(\mathrm{w} / \mathrm{v})$ polyethylene glycol 6000 (PEG) (Sigma) at $4^{\circ} \mathrm{C}$ for three hours. We have shown previously that purified fibronectin is not precipitated by PEG $(4 \% \mathrm{w} / \mathrm{v}) .{ }^{1}$ The resultant precipitate was washed once in $2 \%$ PEG and redissolved in PBS.

IC were also formed in the presence of normal human serum, which acted as a source of complement. Fibronectin was extracted from human serum by affinity chromatography (see below) to yield fibronectin depleted serum (containing $5 \%$ of the original fibronectin concentration measured by enzyme linked immunosorbent assay (ELISA)). This was diluted to give a final IgM concentration of 20 $\mu \mathrm{g} / \mathrm{ml}$ and mixed with goat antihuman IgM antiserum and fibronectin as before.

PURIFICATION OF FIBRONECTIN

Fibronectin was purified by affinity chromatography on gelatin-Sepharose $4 \mathrm{~B}$ using citrated normal human plasma. ${ }^{16}$

TOTAL PROTEIN DETERMINATION

The concentration of protein in PEG $(2 \% \mathrm{w} / \mathrm{v})$ precipitates was determined using the bicinchoninic acid procedure. ${ }^{17}$

\section{ELISA FOR FIBRONECTIN}

The assay was based on that of Selmer et al. ${ }^{18}$ Plastic microtitre plate wells were coated $(100 \mu \mathrm{l} /$ well $)$ with goat antihuman fibronectin (Sigma, Poole, Dorset, UK) $(25 \mu \mathrm{g} / \mathrm{ml}$ in $0.05 \mathrm{M}$ sodium carbonate buffer, $\mathrm{pH} \mathrm{9.6)} \mathrm{and} \mathrm{incubated} \mathrm{at} \mathrm{room} \mathrm{temperature} \mathrm{for} 17$ hours. Each well was then washed twice with $100 \mu \mathrm{l}$ PBS (0.01 M) containing Tween $20(0.05 \% \mathrm{v} / \mathrm{v})$ (PBS-Tween). Excess binding sites on the plate were blocked with PBS-Tween containing 1\% bovine serum albumin (BSA) $(100 \mu \mathrm{l})$ for one hour at room temperature. Standards and samples were added in PBS-Tween-BSA $(100 \mu \mathrm{l})$ and the plate incubated for one hour at room temperature. The standards used were in the range 1.6 to $205 \mu \mathrm{g} / \mathrm{l}$ of protein using fibronectin isolated from normal human plasma. Plates were washed three times with PBS-Tween and rabbit antihuman fibronectin (Dakopatts, Denmark) added (1:1000) in PBS-
Tween-BSA $(100 \mu \mathrm{l})$ before further incubation for one hour at room temperature. After washing, peroxidase conjugated goat antirabbit IgG (Sigma) was added (1:1000) in PBS-Tween-BSA $(100 \mu l)$. After incubation for one hour at room temperature and after washing $(\times 4)$, freshly prepared substrate solution $(100 \mu \mathrm{l})$ was added to each well and the plate incubated at room temperature for 10 minutes (substrate solution: $\mathrm{Na}_{2} \mathrm{HPO}_{4} \cdot 2 \mathrm{H}_{2} \mathrm{O}(0 \cdot 1 \mathrm{M})$, citric acid $(0.034 \mathrm{M})$ containing $\mathrm{H}_{2} \mathrm{O}_{2}(0.01 \%$, w/v) (BDH, Poole, UK), and $o$-phenylendiamine $(4 \cdot 3$ $\mathrm{mM}$ ) (Sigma)). The reaction was terminated by adding $100 \mu \mathrm{l}$ of sulphuric acid $(2.5 \mathrm{M})$ and the absorbance at $492 \mathrm{~nm}$ read using a Uniscan plate reader (Flow Laboratories). Unknown values were calculated by reference to a semilogarithmic standard curve for purified fibronectin. The intraassay coefficient of variation was $8 \%$.

ROCKET IMMUNOELECTROPHORESIS ASSAY FOR F IBRONECTIN

This assay used a monospecific antiserum to fibronectin prepared by the immunodiagnostic research laboratory of the University of Birmingham. The assay has previously been described in detail. ${ }^{19}$

COMPARISON OF ANALYTICAL METHODS FOR FIBRONECTIN DETERMINATION

The amount of fibronectin in $\mathbf{4 5}$ whole sera and $\mathbf{4 2}$ PEG precipitates of sera was measured by both ELISA and rocket immunoelectrophoresis. The samples were from patients with either rheumatoid arthritis or systemic lupus erythematosus.

\section{GEL FIL TRA T IO N}

Elution profiles of serum fibronectin, complement component C3 (C3), and immunoglobulin A (IgA) were compared after gel filtration on Sephacryl S400 (Pharmacia, Uppsala, Sweden) of normal serum and serum from a rheumatoid arthritic patient with systemic vasculitis. Serum $(1 \mathrm{ml})$ was applied to the column $(50 \times 1.5 \mathrm{~cm})$ and proteins eluted with PBS, $\mathrm{pH} \mathrm{7.4}$. The concentrations of fibronectin, $\mathrm{C} 3$, and IgA in the fractions were measured by single radial immunodiffusion using specific antisera and results expressed as relative concentrations for each protein.

TWO DIMENSIONAL

IM MUNOELECTROPHORESIS

Two-dimensional immunoelectrophoresis was performed as described by Clarke and Freeman ${ }^{20}$ on serum and PEG precipitates of serum, using monospecific antiserum to fibronectin in the second dimension. 
SODIUM DODECYL

SULPHATE - POLYACRYLAMIDE GEL

ELECTROPHORESIS (SDS-PAGE)

PEG $(2 \% \mathrm{w} / \mathrm{v})$ precipitates of serum and synovial fluid samples were prepared as described above (for the formation of immune complexes in vitro). Precipitated proteins were separated by the SDSPAGE system of Laemmli ${ }^{21}$ in vertical slabs, using a 4-12\% polyacrylamide gradient containing SDS $(0 \cdot 1 \%)$ and a $5 \%$ polyacrylamide stacking gel. Typically electrophoresis was performed at a constant current of $12.5 \mathrm{~mA} / \mathrm{gel}$ for 17 hours with cooling to $10^{\circ} \mathrm{C}$. Proteins were transferred to nitrocellulose paper (Bio-Rad, California, USA) using electroblotting at $90 \mathrm{~V}$ for one hour at $5^{\circ} \mathrm{C}$. Immunochemical localisation of fibronectin was performed using rabbit antihuman fibronectin antiserum (Dakopatts) and goat antirabbit peroxidase conjugated antiserum (Sigma), followed by colour formation with diaminobenzidine and hydrogen peroxide as substrates for the peroxidase.

\section{CLINICAL SPECIMENS}

Paired samples of synovial fluid and serum were obtained from 17 patients with rheumatoid arthritis and 16 with osteoarthritis. Serum was also obtained from six normal controls. The specimens were centrifuged at $1000 \mathrm{~g}$ for $10 \mathrm{~min}$ and the supernatants removed and used immediately for studies of IC. PEG precipitates were produced as described above. Fibronectin was measured by the ELISA technique and Clq by single radial immunodiffusion using an assay kit supplied by Mercia Diagnostics.

\section{Results}

ASSOCIATION OF FIBRONECTIN WITH IMMUNE COMPLEXES FORMED IN VITRO The formation of IgM and anti-IgM IC was shown by measuring PEG precipitable protein (Table 1).

Table 1 Precipitation of fibronectin by PEG during in vitro immune complex formation in the absence of serum $(n=6)$

\begin{tabular}{lllll}
\hline $\begin{array}{l}\text { Proteins added } \\
\text { to fibronectin }\end{array}$ & $\begin{array}{l}\text { Total protein } \\
\text { in PEG } \\
\text { precipitate } \\
(\mathrm{mg} / \mathrm{ml})\end{array}$ & $\begin{array}{l}\text { Fibronectin } \\
\text { in PEG precipitates }\end{array}$ & $\mu \mathrm{\mu g} / \mathrm{ml}$ & $\begin{array}{l}\text { \% Control } \\
\text { value }\end{array}$ \\
\hline $\begin{array}{l}\text { IgM alone } \\
\begin{array}{c}\text { Anti-IgM } \\
\text { and IgM }\end{array}\end{array}$ & $3.7(1.7)$ & $0.23(0.06)$ & $100(26)$ \\
\hline
\end{tabular}

Values are mean (SD).

*Significantly higher by Mann-Whitney $U$ test $(p<0 \cdot 01)$.
Table 2 Precipitation of fibronectin by PEG during in vitro complex formation in the presence of fibronectin depleted human serum $(n=8)$

\begin{tabular}{|c|c|c|}
\hline \multirow{2}{*}{$\begin{array}{l}\text { Proteins added to } \\
\text { serum }\end{array}$} & \multicolumn{2}{|c|}{ Fibronectin in PEG precipitate } \\
\hline & $\mu g / m l$ & $\%$ Control value \\
\hline $\begin{array}{l}\text { Fibronectin } \\
\text { Fibronectin and } \\
\text { anti-IgM }\end{array}$ & $\begin{array}{l}0.07(0.03) \\
0.43(0.14)^{*}\end{array}$ & $100(40)$ \\
\hline
\end{tabular}

Values are mean (SD).

${ }^{*}$ Significantly higher by Mann-Whitney $U$ test $(p<0.01)$.

Analysis of the PEG precipitates by ELISA showedọ the amount of precipitated fibronectin was signifi- $\vec{O}$ cantly increased when IC were produced $(\mathrm{p}<0.01$ by Mann-Whitney $U$ test). Exogenous fibronectin $\triangle$ was a constituent of PEG precipitable complexes윽 formed by the addition of anti-IgM to fibronectindepleted serum (Table 2). The amount of fib-O ronectin precipitated was significantly greater when:्? IC were formed than in the control where antibody was omitted (Table 2). The relative amount of fibronectin precipitated was similar when IC weese synthesised using purified IgM or human serum.

GEL FILTRATION

Chromatography of normal serum showed IgA, C3, and fibronectin were only present in a single peak (Fig. 1). Serum from a patient with rheumatoid $\stackrel{\complement}{\complement}$ vasculitis showed a proportion of each of these $\overrightarrow{\overrightarrow{0}}$ proteins was present in high molecular weight forms (Fig. 1). This suggests that IC were present in the serum and contained $\mathrm{IgA}, \mathrm{C} 3$, and fibronectin.

TWO DIMENSIONAL

IM MUNOELECTROPHORESIS

Normal serum gave a single peak with antifibronectin in the second dimension (Fig. 2). Serum from a rheumatoid patient showed a number of components were present, including a slow moving윽 immunoreactive fibronectin moiety.

SDS-PAGE AND IMMUNOBLOTTING SDS-PAGE of PEG precipitates of serum and synovial fluid followed by immunoblotting with ${ }^{N}$ antifibronectin antiserum was performed for patients with osteoarthritis (OA) and with rheumatoido arthritis (RA). Examples are shown in Figs 3 and 40 Fibronectin was present mainly as a polypeptide of molecular weight 220000 in serum from a patient $\stackrel{?}{+}$ with OA (Fig. 3). There was evidence, however, of 0 lower molecular weight forms of fibronectin in $\overrightarrow{0}$ synovial fluid ${ }^{\circ}$ from the same patient. In PEG $_{\Omega}^{\mathbb{Q}}$ 


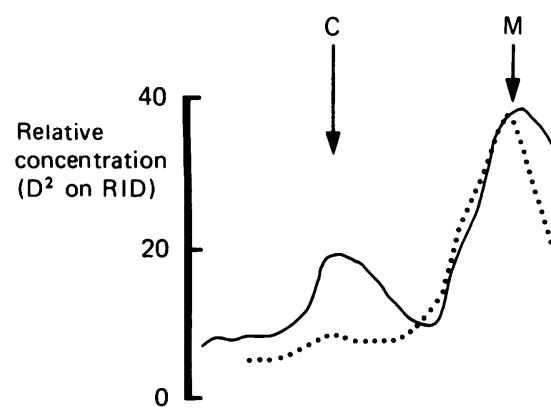

C3
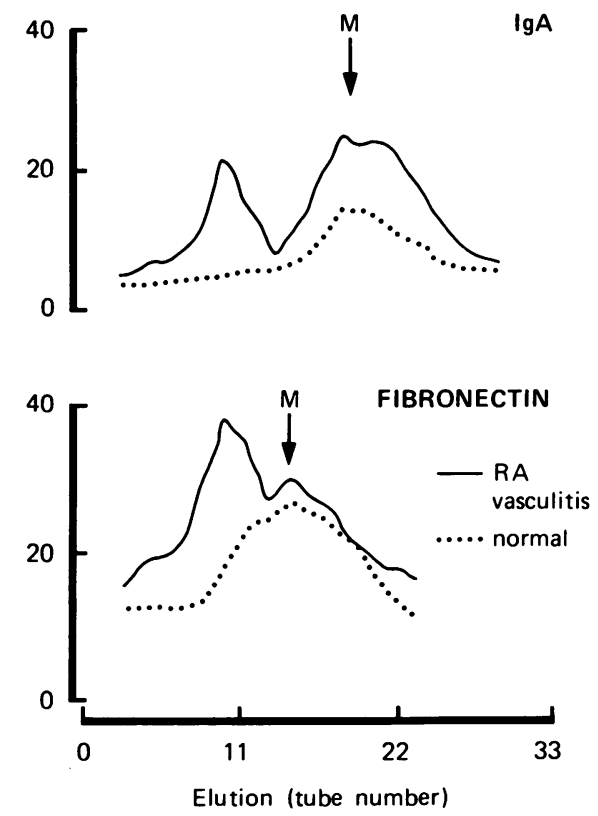

Fig. 1 Elution profiles of serum fibronectin, IgA, and C3 from Sephacryl $\$ 400$ column $(50 \times 1.5 \mathrm{~cm})$ eluted with $P B S, p H$ 7.4. $R A$ vasculitis serum (-), normal serum $(\cdot \cdots) . C=$ complexed $; M=$ monomeric. $R I D=$ radial immunodiffusion.

precipitates of RA sera (Fig. 4) native fibronectin (molecular weight 220000 ) and some smaller molecular weight polypeptides were observed. In contrast, a PEG precipitate of RA synovial fluid contained little native fibronectin, but many forms of lower molecular weight with immunoreactivity to antifibronectin antiserum were evident.

FIBRONECTIN AND CIq IN RA AND OA PEG PRE CI P I T A T ES

Significantly more fibronectin was present in PEG precipitates from RA synovial fluid than from OA synovial fluid ( $\mathrm{p}<0.02$ by Student's unpaired $t$ test). The differences in serum were less pronounced (Table 3). The level of fibronectin in PEG precipitates of synovial fluid was greater than in serum for both groups of patients $(\mathrm{p}<0.01$ by Student's paired $t$ test). Conversely $\mathrm{Clq}$ concentrations in serum PEG precipitates were greater than those of synovial fluid. Therefore the ratio of serum/synovial fluid PEG precipitable fibronectin was low (less than 1) and for C1q was high (greater than 1).

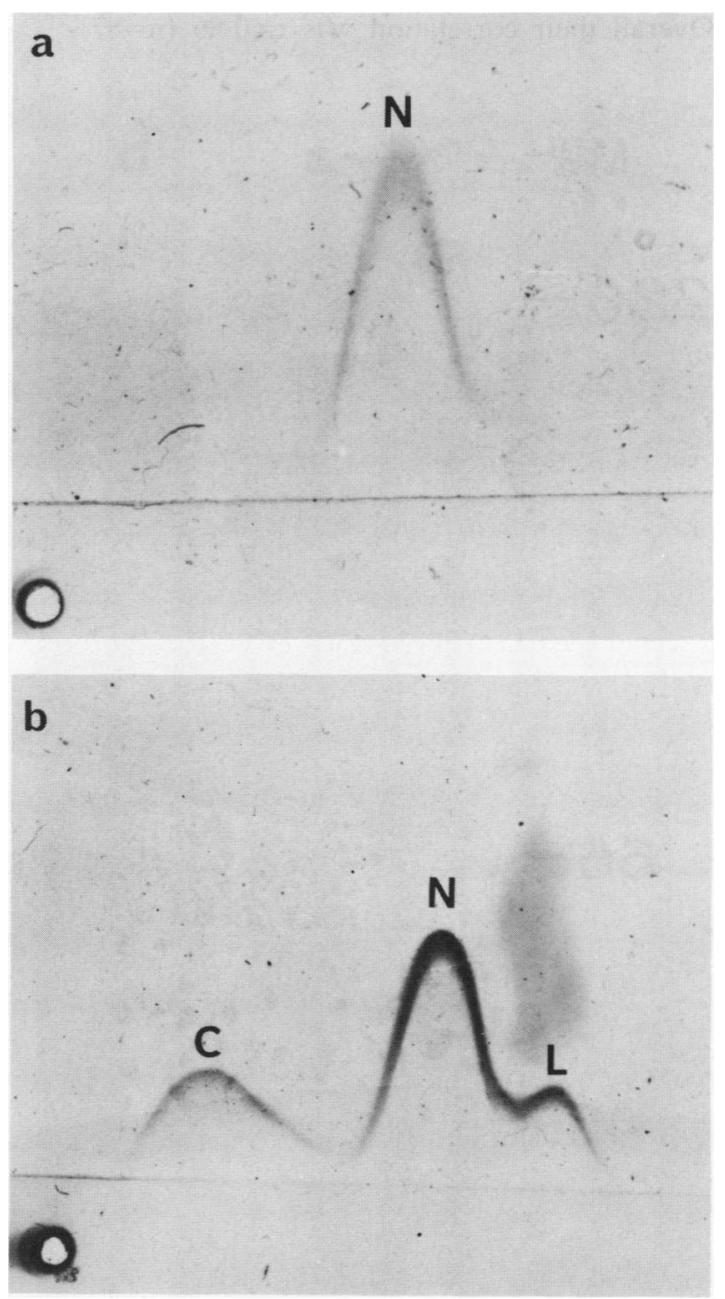

Fig. 2 Two dimensional immunoelectrophoresis using antifibronectin antiserum in the second dimension gel. (a) Normal human serum; (b) SLE serum. $N=$ native fibronectin; $C=$ complexed fibronectin; $L=$ low molecular weight fibronectin. 
COMPARISON OF ELISA AND ROCKET

TECHNIQUES

The presence of fibronectin fragments in some PEG precipitates raises a potential analytical problem: different antibodies may possess different specificities for fibronectin fragments. A second analytical difficulty is interference in the ELISA assay by rheumatoid factor. A comparison of ELISA and rocket assays using antisera to fibronectin from different sources showed these problems were not important. The two assays gave similar correlations with serum and with PEG precipitates: the Pearson correlation coefficients were $r=0.69(n=45)$ for serum and $r=0.89(n=42)$ for PEG precipitates. Overall their correlation was $r=0.86(n=87)$.

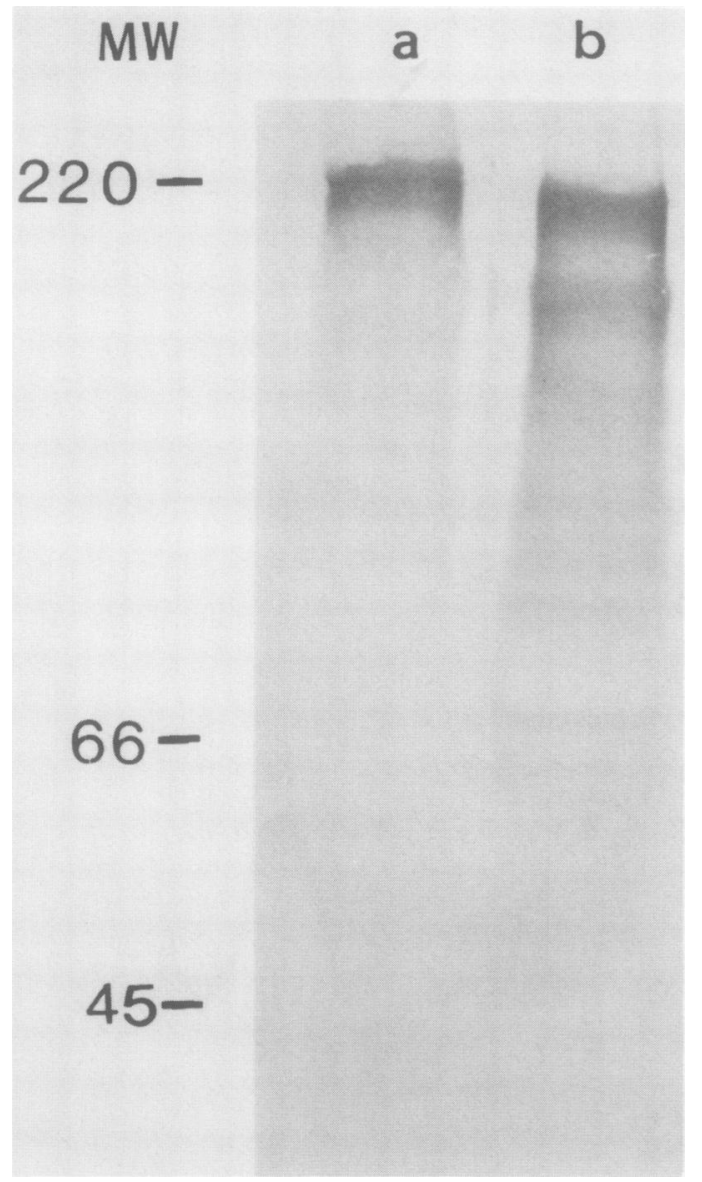

Fig. $3 P A G E(4-12 \%)$ of $2 \%$ PEG precipitates of serum and synovial fluid, immunoblotted with antifibronectin antiserum. Paired serum (a) and synovial fluid $(b)$ were prepared from a patient with osteoarthritis. $M W=$ molecular weight in kilodaltons.

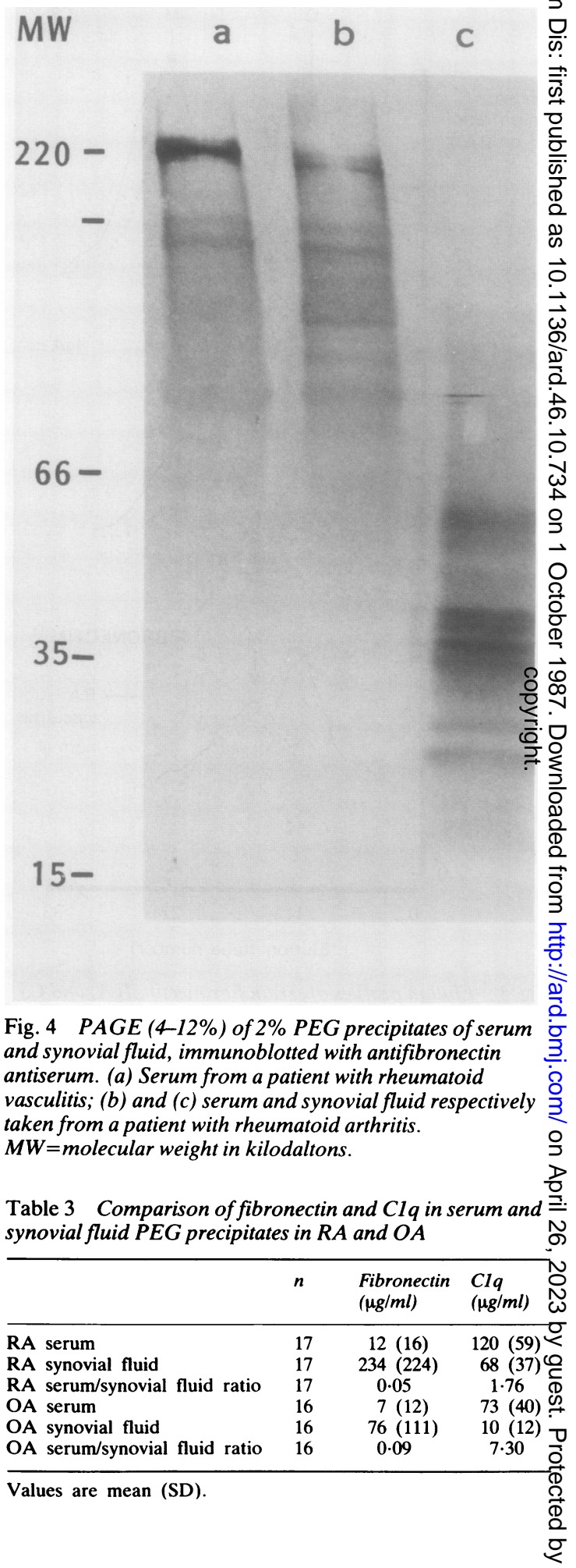




\section{Discussion}

These results strongly suggest that fibronectin is a component of IC. The coelution of fibronectin with high molecular weight $\mathrm{C} 3$ and $\operatorname{IgA}$ in the rheumatoid vasculitic serum shows its presence in immune complexes is not merely an in vitro artefact produced by IC isolation by PEG. The amount of fibronectin in IC depends on their site of formation. Synovial fluid complexes contained more fibronectin than serum IC. This may be due to differences in the nature of the fibronectin molecule in synovial fluid. Although fibronectins are formed from a single gene, there are post-transcriptional differences in its polypeptide chain structure at different sites. ${ }^{22} 23$ Thus synovial fluid fibronectin is different from the serum form. ${ }^{24-27}$ Using SDSPAGE with immunoblotting, however, we estimated the molecular weight of reduced serum and synovial fluid fibronectin each to be 220000 , which agrees with previous reports on plasma ${ }^{6}$ and cell surface fibronectins. ${ }^{28}$

The immunoblotting studies show fibronectin in IC may be partially or completely degraded, most notably in synovial fluid complexes. Inflamed joints contain free proteolytic enzymes and macrophages and polymorphonuclear leucocytes capable of degrading fibronectin both enzymically and by a free radical mechanism. The propensity of fibronectin to damage by these mechanisms may be more marked in the synovial fluid form of the molecule. The altered pattern of immunoreactivity of serum fibronectin on two dimensional immunoelectrophoresis can be explained by both partial degradation and by complexing with other proteins. Such complexing could be similar to the $\operatorname{IgA} / \alpha_{1}$ antitrypsin complex seen in rheumatoid arthritic sera and synovial fluids. ${ }^{29} 30$ Enzymically formed fibronectin fragments possess altered biological activity compared with the active molecule. ${ }^{31}{ }^{32}$ It has also been shown that some fragments may have specific effects not present in the intact molecule with a significant stimulating action on fibroblasts. The implication is that the binding of native or fragmented fibronectin to IC may influence their biological role or their removal from sites of immune related inflammation and tissue damage. Bykowska et al have shown that proteolysis of plasma fibronectin influences its apparent concentration in two immunoassays based on electroimmunoassay and immunoturbidimetric techniques. ${ }^{33}$ Our own results, however, suggest that in PEG precipitates the levels of fibronectin measured immunochemically are similar in two different assays-ELISA and rocket immunoelectrophoresis. This suggests that the levels of fibronectin in PEG precipitates found in our assay systems do not result from an artefact produced by partial degradation.

The in vitro formation of IC shows the relative amount of fibronectin precipitated by PEG is similar in the presence and absence of serum. Only trace amounts of serum proteins will have been added with the antiserum to IgM, including a very small quantity of complement proteins. These results therefore suggest that fibronectin can bind directly to IC and that this binding is not mediated by C1q. Conversely, it cannot be argued from our results that $\mathrm{Clq}$ binding does not account for a part of fibronectin adherence to IC; indeed there is considerable evidence supporting such a suggestion. ${ }^{3} 13$ 34-36 Nevertheless, the analyses of paired serum and synovial fluid PEG precipitates provide further evidence that fibronectin adherence does not depend on the amount of C1q in IC. The relative amounts of fibronectin and $\mathrm{Clq}$ in IC are dependent upon the site at which IC are formed.

Although these results point to a role for fibronectin in IC formation, this will only be of biological significance if it can alter their handling in vivo. The demonstration of specific macrophage receptors for fibronectin ${ }^{37}$ suggested a potential role. The work of Saba and Jaffe showed that fibronectin is an opsonic protein, ${ }^{11}$ and more recent studies by Simpson and Boughton have shown its opsonic role is equal to that of IgG and complement in certain circumstances. ${ }^{12}$ Using the clearance of a charged colloid (dextran sulphate) as a model, Walton et al showed that high molecular weight dextran sulphate forms complexes containing fibronectin in rat plasma in vivo ${ }^{38}$; its parenteral administration lowers plasma fibronectin acutely in a dose related fashion. The plasma changes are accompanied by deposition of dextran sulphate (shown histochemically as metachromatic material) and of fibronectin (shown by specific immunofluorescence) in an identical distribution within reticuloendothelial cells of rat liver and spleen. If one transposes IC for "charged colloid' it is apparent that fibronectin has the potential to modify the clearance of IC and control some features of immunologically mediated disease. There is already evidence that fibronectin can bind to certain forms of IgG,${ }^{39}$ to DNA,${ }^{40}$ and possibly to C3. ${ }^{41}$ It also has a major role in binding to bacteria. ${ }^{42}$ It is thus probable that fibronectin is an important functional constituent of IC in rheumatic diseases. Our current results support this, though the exact pathogenic significance of the interaction of fibronectin with IC needs further definition.

We thank the Arthritis and Rheumatism Council, the Joint Research Board of the Medical College of St Bartholomew's Hospital, and the Peel Medical Foundation for their help and support. 


\section{References}

1 Coppock J S, Scott D L. Carter S D, Moreland T M, Robinson M W. Fibronectin in polyethylene glycol precipitates: evidence for a role in immune complexes. Rheumatol Int 1986; 6: 79-83.

2 Carter S D, Scott D L, Elson C J. Fibronectin associated with immunoglobulin aggregates in sera and synovial fluid in rheumatoid arthritis. Br J Rheumatol (in press).

3 Sorvillo J, Gigli I, Pearlstein E. Fibronectin binding to Clq associated with antigen-antibody complexes in EDTA-treated plasma. Scand J Immunol 1986; 23: 153-60.

4 Ferraccioli G, Karsh J, Osterland C K. Interaction between fibronectin, rheumatoid factor and aggregated gamma globulins. J Rheumatol 1985; 12: 680-4.

5 Yamada K M, Olden K. Fibronectins-adhesive glycoproteins of cell surface and blood. Nature 1978; 275: 179-84.

6 Mosesson M W, Amrani D L. The structure and biologic activities of plasma fibronectin. Blood 1980; 56: 145-58.

7 Ruoslahti E, Engvall E, Hayman E G. Fibronectin: current concepts of its structure and function. Coll Relat Res 1981; 1: 95-128.

8 Mosher D F. Fibronectin. Prog Hemost Thromb 1980; 5: 111-51.

9 Pierschbacher M D, Ruoslahti E. Cell attachment activity of fibronectin can be duplicated by small synthetic fragments of the molecule. Nature 1984; 309: 30-3.

10 Molnar J, Gelder F B, Lai M Z, Sicfung G E, Credo R B, Lorand $\mathrm{L}$. Purification of opsonically active human and rat cold insoluble globulin (plasma fibronectin). Biochemistry 1979; 18: 3909-16.

11 Saba T M, Jaffe E. Plasma fibronectin (opsonic glycoprotein): its synthesis by vascular endothelial cells and role in cardiopulmonary integrity after trauma as related to reticuloendothelial function. Am $J$ Med 1980; 68: 577-94.

12 Simpson A W, Boughton V J. Fibronectin as an opsonic regulator of monocyte phagocytosis. J Clin Pathol 1984; 37: 787-9.

13 Menzell E J, Smolen J S, Liotta L, Reid K B M. Interaction of fibronectin with $\mathrm{Clq}$ and its collagen-like fragment (CLF). FEBS Lett 1982; 129: 188-92.

14 Anderson B, Rucker M, Entwistle R, Schmid F R, Wood G W Plasma fibronectin is a component of cryoglobulins from patients with connective tissue and other diseases. Ann Rheum Dis 1981; 40: 50-4.

15 Scott D L, Almond T J, Naqvi S N H, Lea D J, Stone R, Walton $\mathrm{K} \mathrm{W}$. The significance of fibronectin in cryoprecipitation in rheumatoid arthritis and other disorders. $J$ Rheumato 1982; 9: 514-8.

16 Scott D L, Bedford P A, Walton K W. The purification of plasma fibronectin antigen and antiserum $J$ Immunol Methods 1981; 43: 29-33.

17 Smith P K, Krohn R I, Hermanson G T, et al. Measurement of protein using bicinchoninic acid. Anal Biochem 1985; 150: 76-85.

18 Selmer J, Eriksen H O, Clemmensen I. Native and degraded fibronectin. New immunological methods for distinction. Scand $J$ Clin Lab Invest 1984; 44: 57-63.

19 Scott D L, Farr M, Crockson A P, Walton K W. Synovial fluid and plasma fibronectin levels in rheumatoid arthritis. Clin Sci 1982; 62: 71-6.

20 Clarke H G M, Freeman T. Quantitative immunoelectrophoresis of human serum proteins. Clin Sci 1968; 35: 403-13.

21 Laemmli U K. Cleavage of structural proteins during assembly of the head of bacteriophage T4. Nature 1970; 227: 680-5.

22 Schwarzbauer J E, Paul J I, Hynes R O. On the origin of species of fibronectin. Proc Natl Acad Sci USA 1985; 82: 1424-8.
23 Oldberg A, Ruoslahti E. Evolution of the fibronectin gene. Biol Chem 1986; 261: 2113-6.

24 Clemmensen I, Andersen R B. Different molecular forms of fibronectin in synovial fluid. Arthritis Rheum 1981; 24: 1261-7. $\overrightarrow{\bar{F}}$

25 Scott D L, Carter S D, Coppock J S, Robinson M W, Walton K W. Differences between plasma and synovial fluid fibronectin. Rheumatol Int 1985; 5: 49-54.

26 Carnemolla B, Cutolo M, Castellani P, Balza E, Raffanti S, $\overline{\bar{c}}$ Zardi L. Characterisation of synovial fluid fibronectin from $\overrightarrow{\mathbb{D}}$ patients with rheumatic inflammatory disease and healthyo subjects. Arthritis Rheum 1984; 27: 913-21.

27 Carsons S, Lavietes B B. Diamond H S, Kinney S G. The immunoreactivity, ligand, and cell binding characteristics of $\vec{O}$ rheumatoid synovial fluid fibronectin. Arthritis Rheum 1985; 28:601-12.

28 Yamada K M, Schlesinger P H, Kennedy P W, Pastan I. O Characterisation of a major fibroblast cell surface glycoprotein. Biochem J 1977; 16: 5552-9.

29 McDonald J A, Baum B J, Rosenberg D M, Kelman J A, Brin S S, Crystal R G. Destruction of a major extracellular adhesive: glycoprotein (fibronectin) of human fibroblasts by neutralo proteases from polymorphonuclear leucocyte granules. $L a b \mathrm{~W}$ Invest 1979; 40: 350-7.

30 Furie M D, Rifkin D B. Proteolytically derived fragments ofo human plasma fibronectin and their localisation within the intact molecule. J Biol Chem 1980; 255: 3134-40.

31 Humphries M J, Ayad S R. Stimulation of DNA synthesis by cathepsin D digests of fibronectin. Nature 1983; 305: 811-3.

32 Savill C M, Ayad S R. The mitogenic activity of a heparinbinding fibronectin fragment (Mr 35,000) produced by cathepsin D digestion. Anticancer Res 1986; 6: 321-6.

33 Bykowska K, Wegrzynowicz Z, Lopaciuk S, Kopec M. Effecto of proteolysis on quantification of plasma fibronectin concenta-tion by two immunoassays (electroimmunoassay and immu两turbidimetric technique). Thromb Haemost 1985; 53: 377-80 .

34 Bing D H, Almeda S, Isliker $\mathbf{H}$, Lahar J, Hynes $\mathrm{R}$ O. Fibronectin binds to the $\mathrm{Clq}$ component of complement. Proco Natl Acad Sci USA 1982; 79: 4198-201.

35 Pearlstein E, Sorvillo J, Gigli I. The interaction of human plasma fibronectin with a subunit of the first component of complement C1q. J Immunol 1982; 128: 2036-9.

36 Reid K B M, Edmonson J. Location of the binding site in subcomponent $\mathrm{Clq}$ for plasma fibronectin. Acta Pathol Microbiol Immunol Scand [Suppl] 1984; 284: 11-17.

37 Bevilacqua M P, Amrani D, Mosesson M W, Bianco C. Receptors for cold-insoluble globulin (plasma fibronectin) ond human monocytes. J Exp Med 1981; 153: 42-60.

38 Walton K W, Almond T J, Robinson M, Scott D L. AnO experimental model for the study of the opsonic activity of fibronectin in the clearance of intravascular complexes. $\mathrm{Br} j \mathrm{j}$ Exp Pathol 1984; 65: 191-200.

39 Hautanen A, Keski-Oja J. Affinity of myeloma IgG proteins for fibronectin. Clin Exp Immunol 1983; 53: 233-8.

40 Siri A, Balza E, Carnemolla B, Castellani P, Borsi L, Zardi L. DNA-binding domains of human plasma fibronectin. Eur Biochem 1986; 154: 533-8.

41 Hautanen A, Keski-Oja J. Interaction of fibronectin with complement component C3. Scand J Immunol 1983; 17: 225-30.

42 Proctor R A. Prendergast E, Mosher D F. Fibronectin mediates N attachment of Staphylococcus aureus to human neutrophils. N Blood 1982; 59: 681-7.

43 Eriksen H O, Espersen F, Clemmensen I. Opsonic activity of fibronectin in the phagocytosis of Staphylococcus aureus by polymorphonuclear leukocytes. Eur J Clin Microbiol 1984; 3든 108-12. 